\title{
Synthesis of Bio-Photocatalysts and their Application for the Degradation of Organic Pollutants
}

\author{
Jean Bedel Batchamen Mougnol, Elvis Fosso-Kankeu, Ali R. Al Alili, Neeraj Kumar, Rashi Gusain, \\ Hemant Mittal and Suprakas S. Ray
}

\begin{abstract}
Photocatalysis is a cost-effective and efficient approach to remove the toxic organic pollutants from wastewater. Eco-friendly approaches, such as the development of photocatalysts using renewable materials, have been discussed in an attempt to follow green technologies. These renewable innovations are of concern because they are low cost and easy to assemble. A great deal of attention has recently been paid to moving towards environmentally friendly and keeping the environment away from pollutants, which is why several reports have been issued. The use of plants (leaves, stems, flowers and fruits) on their process of development and the use of these green synthetic materials in photo-catalysis has been researched and documented on the treatment of wastewater. This paper will focus on the review of the different types of photo-biocatalysts; their synthesis and application for the photo-degradation of organic pollutants.
\end{abstract}

Keywords- Photo-Biocatalysis; Organics Pollutants; Degradation.

\section{INTRODUCTION}

Low cost and non-toxic photo-catalysts such as $\mathrm{ZnO}$ and $\mathrm{TiO} 2$ have been identified as outstanding candidates for light-duty water depollution [1]. Nevertheless, their use is constrained by the wide bandgap that imposes a UV constraint on the generation of electron-hole pairs [2-5]. For example, to achieve a successful and sufficient energy supply in the system, the following will need to adhere: the semiconductor will need to extend its ability in the lifespan of charge carriers [6]. Environmental remediation has been a challenge for researchers, which is why new treatment approaches, such as photo-catalysis, are being investigated to ensure safe and reliable clean water. Industries such as cosmetics, paper and leather manufacture wastewater containing a variety of organic pollutants such as methylene blue ( $\mathrm{MB}$ ), methyl orange (MO),

J.B. Batchamen Mougnol and E. Fosso-Kankeu are with the Water Pollution Monitoring and Remediation Initiatives Research Group, School of Chemical and Minerals Engineering, North-West University, Potchefstroom, South Africa

A.R. Al Alili and H. Mittal are with the Department of Mechanical Engineering, Khalifa University of Technology, Abu Dhabi, UAE

N. Kumar, R. Gusain and S.S. Ray are with the DST-CSIR National Centre for Nanostructured Materials, Council for Scientific and Industrial Research, Pretoria 0001, South Africa

R. Gusain and S.S. Ray are with Department of Applied Chemistry, University of Johannesburg, Doornfontein 2028, Johannesburg, South Africa dyes, rhodamine blue (RhB) and many others [7].

These industrial effluents pollute natural reservoirs such as rivers, lakes, and dams. There has been substantial growth in the need to develop effective economic approaches for handling water. Several processes, including microbial oxidation, reverse osmosis, adsorption and photo-catalysis, have been used to clear organic pollutants from wastewater. These approaches have one type of downside or another, for example, microbial degradation is time-consuming, unsuccessful for some of the organic pollutants, and may generate carcinogenic materials [8]. Other processes, such as adsorption, although widely studied, appear to be expensive and the regeneration process is difficult [9].

However, the general downside to all these approaches is that they sometimes convert organic pollutants from one step to another and do not fully remove these contaminants, thus producing secondary pollutants. The key advantage of photo-catalysis over other approaches is that it distinguishes organic pollutants from less toxic intermediates. This is an innovative oxidation process that is mainly used because it is cheap and environmentally safe [10].

For the reasons pointed out above, environmentally sustainable methods are required to prevent the degradation of the ecosystem. Eco-friendly approaches, such as the synthesis of nanostructures using green technology, have been investigated to reduce these. These green nanostructures are of concern because they are cost-effective and simple to manufacture. The simplest and safe way to manufacture these nanostructured semiconductor materials is by using plant agents [11]. In the recent past, many materials such as activated charcoal, biochar and low-cost adsorbents produced from a range of resources have been studied for the decontamination of water. Recently, the use of nanostructured materials for scavenging and oxidation of harmful water pollutants has acquired enormous significance due to their peculiar size-dependent properties such as wide surface area, short intra-particle diffusion time, compressibility with marginal surface area reduction, excellent resilience, exceptional reusability and recyclability [12].

Bio-based nanoparticles (NPs) were also used for photocatalytic degradation of toxins in aqueous solutions. Various plant sections, such as leaves, buds, seeds, pods, fruit peels, stems, roots, etc., have been used for NP synthesis [13]. Many types of plant biomass may be used for the synthesis of NPs. Some research groups used fresh biomass for extraction, 
while others used dry/powdered biomass for the same purpose [12]. In recent years, biogenic processing of nano-sized materials has offered an enticing alternative to traditional routes due to their low cost and environmental benignity. However, the optimisation and conservation of key characteristics such as size regulation, monodispersity and durability of biologically derived NPs are of concern [12].

\section{ORganic Pollutants In WASTEWATER}

More than 0.7 million tons of organic dye are manufactured globally per year. It is known that over 10,000 commercially available dyes are listed as acidic, reactive, dispersive, vat, metal complex, mordant and sulfur dyes. For a variety of factors, reactive dyes have been described as the most environmentally harmful compounds in clothing dye effluents. Second, because of their desired output and their growing market share, reactive dyes are used intensively. Third, they are very soluble and about $10-15 \%$ of the weight of the reactive dye added is discharged from various industries and households. Fourth, traditional wastewater treatment systems, which depend on sorption and aerobic biodegradation, have a poor recovery capacity for reactive and other anionic soluble dyes. As a result, they cause tainted water sources and environmental concerns, and contaminants are moved to another process and are not discarded [14].

\section{VARIOUS PHOTO-BIOCATALYST}

Though many photo-catalyst have been studied and applied in the degradation of organics pollutants, we have come to realize that they are still room for improvement and application of an environmentally friendly technology. Degradation performance of various organic compounds is strongly dependent on experimental conditions such as light irradiation source, reaction time, pollutants form and photo-biocatalyst weight [15]. Any of the contaminants are biologically recalcitrant and inhibitory to tissues, which dramatically decrease the capacity of the microorganism to biodegrade substances before or in practice after treatment [17].

In recent years, a recurring mix of heterogeneous photocatalytic and biological processes for the treatment of various toxic effluents has been proposed. Progress is focused on the achievement of appropriate biodegradability for the shortest photocatalytic degradation (optimal treatment) and the subsequent application of biological degradation, which makes the overall procedure quicker and more desirable. The green synthesis of metal oxides has been studied and concluded in various applications of photo-biocatalyst on the mineralization of recalcitrant organic pollutants in various aqueous solution [14].

The following sections discuss the different types of pho-biocatalysts used in many applications, their effectiveness and optimisation on the removal of pollutants.

\section{A. $\mathrm{GO} x / \mathrm{TiO}_{2} / \mathrm{Fe}^{2+} /$ Metal Foam Photo-biocatalyst}

The formation of the $\mathrm{GOx} / \mathrm{TiO}_{2} / \mathrm{Fe}^{2+} / \mathrm{Metal}$ Foam Photo-biocatalyst stated by [17-19] was reported in comparison of the enzymes and the microorganisms. The enzymes were preferred rather than microorganisms based on their ability to be handled and stored. THey are also believed to be highly productive and are produced by microorganisms. The most popular enzyme of interest is glucose oxidase (GOx), which creates hydrogen peroxide in situ in the presence of glucose [15]. FOX1 method can be used to measure the produced $\mathrm{H}_{2} \mathrm{O}_{2}$ after the production of the photo-biocatalyst, which can later be utilized in wastewater as it holds a strong oxidization affinity. It has several advantages such: a) destroying toxic organics pollutants without pollution transfer to another phase, b) does not produce harmful residues, c) can be combined with other catalysts and other oxidizers, d) efficient in treating almost all organics pollutants and removing some toxic metals, e) works for water disinfection and destruction of microorganisms [20].

One of the most widely used enzymes known as oxidoreductase GOx, catalyzes the reaction by which all electrons ( $\beta$ glucose) are taken from the substrate and transferred to $\mathrm{O}_{2}$ to produce in situ $\mathrm{H}_{2} \mathrm{O}_{2}$ [11].

$$
\mathrm{C}_{6} \mathrm{H}_{12} \mathrm{O}_{6}+\mathrm{O}_{2}+\mathrm{H}_{2} \mathrm{O} \rightarrow \mathrm{H}_{2} \mathrm{O}_{2}+\mathrm{C}_{6} \mathrm{H}_{12} \mathrm{O}_{7}
$$

Then, with hydrogen peroxide, ferrous ions respond by producing ferric ions and hydroxyl radicals [21]. A UV-A lamp $<390 \mathrm{~nm}$ with an energy band of $3.2 \mathrm{eV}$ was glazed with the $\mathrm{TiO}_{2}$ semiconductor photo-catalyst to generate a positive charge hole and free electrons [22]. Doing so revealed the photo-catalyst effectiveness under UV-A lamp radiation.

\section{i. Immobilization of $\mathrm{TiO}_{2}$ nanoparticles on $\mathrm{AgO}$ metal-foam}

The preparation and the immobilisation of $\mathrm{TiO}_{2} \mathrm{NPs}$ on $\mathrm{AgO}$ using Sonoplus Ultrasonic Homogenizer HD 2200 (Germany) was considered. This method was successfully approached where the immobilization of $\mathrm{TiO}_{2}$ on $\mathrm{AgO}$ metal foam was undertaken to generate the photo-catalyst under particular parameters such as temperature, $\mathrm{pH}$ and chemical additives. At a selected temperature, a measured concentration of $\mathrm{HCl}$ addition to preserve a $\mathrm{pH}$ of 5.5 was carefully determined in the production of photo-catalyst [23].

\section{ii. Immobilization of $\mathrm{GOx}$ on $\mathrm{TiO}_{2} / \mathrm{AgO}$ metal-foam}

There are various methods for the immobilization of enzymes, such as physical adsorption, covalent bonding and trapping [24, 25]. The advantages of using the enzymes are, low cost and minimal denaturation which are the most important criteria for selecting the right treatment [26]. Among the various methods mentioned on the immobilisation of enzymes, the physical adsorption of enzyme (GOx) was preferred [27] to be suitable on the immobilisation on the $\mathrm{TiO}_{2} / \mathrm{AgO}$ metal-foam to produce a photo-biocatalyst.

The addition of GOx to the preparation mentioned in Section A(i) above the $\mathrm{TiO}_{2} / \mathrm{AgO}$ metal foam immobilization was carried out. Where a new chemical additive phosphate buffer (PBS) was applied, a photo-biocatalyst was obtained at a new temperature and $\mathrm{pH}$ value $[28,29]$.

Table I below displays the data obtained at various periods and the ratio combination with and without the inclusion of UV and GOx, and it has been found that the mixture of the 
$\mathrm{TiO}_{2}+\mathrm{Fe}+\mathrm{GOx}+\mathrm{UV}$ has a higher efficiency in the removal of malachite green (MG) from the aqueous solution.

TABLE I: DESCRIPTION OF EXPERIMENTAL EFFECTS OF MG REMOVAL UNDER UV LIGHT WITH $[\mathrm{MG}] 0=20 \mathrm{MG} / \mathrm{L}$; INLET FLOW RATE $=5 \mathrm{ML} / \mathrm{MIN}$ [23]

\begin{tabular}{cccc}
\hline $\begin{array}{c}\mathrm{MG} \\
\text { Decolourization } \\
\text { process }\end{array}$ & \multicolumn{2}{c}{ Decolourization $(\%)$} & $\begin{array}{c}\text { Decolourization } \\
\text { rate constant }(\mathrm{k}, \\
\left.\text { min }^{-1}\right)\end{array}$ \\
\hline $\mathrm{TiO}_{2}+\mathrm{UV}$ & 42.17 & 59.15 & $2.8 \times 10^{-2}$ \\
$\mathrm{TiO}_{2}+\mathrm{Fe}$ & 49.27 & 55.15 & $3.3 \times 10^{-2}$ \\
$\mathrm{TiO}_{2}+\mathrm{Fe}+\mathrm{UV}$ & 55.07 & 64.67 & $3.9 \times 10^{-2}$ \\
$\mathrm{TiO}_{2}+\mathrm{GOx}$ & 50.03 & 54.64 & $3.4 \times 10^{-2}$ \\
$\mathrm{TiO}_{2}+\mathrm{GOx}+\mathrm{Fe}$ & 58.55 & 63.54 & $4.5 \times 10^{-2}$ \\
$\mathrm{TiO}_{2}+\mathrm{GOx}+\mathrm{UV}$ & 66.09 & 71.73 & $5.3 \times 10^{-2}$ \\
$\mathrm{TiO}_{2}$ & 84.36 & 89.85 & $8.9 \times 10^{-2}$ \\
$+\mathrm{Fe}+\mathrm{GOx}_{\mathrm{HOV}}$ & & & \\
\hline
\end{tabular}

The photo-biocatalyst mixture of Glucose oxidase, titanium dioxide, ferrous iron and metal foam $\left(\mathrm{GOx} / \mathrm{TiO}_{2} / \mathrm{Fe}^{2+} / \mathrm{MF}\right)$ had a high tendency to extract $84.37 \%$ malachite green (MG) from the aqueous solution under UVA-LED for 20 minutes. It has also been shown that increasing the glucose dose still has a beneficial effect on the elimination of MG as stated by Abdi et al. [23].

\section{B. $\mathrm{NiFe}_{2} \mathrm{O}_{4} / \mathrm{T} / \mathrm{GO} x$ Photo-biocatalyst}

To examine the degree of mineralization of indigo carmine (IC) attained during photo-degradation, a complete organic carbon (TOC) experiment was conducted for $\mathrm{NiFe}_{2} \mathrm{O}_{4} / \mathrm{T} / \mathrm{GOx}$ photo-biocatalyst. The use of tannin and GOx was both applied in the synthesis of the $\mathrm{NiFe}_{2} \mathrm{O}_{4} / \mathrm{T} / \mathrm{GOx}$ photo-biocatalyst. $\mathrm{NiFe}_{2} \mathrm{O}_{4}$ was prepared using the solvothermal process [26] and was functionalized with tannin. GOx was then immobilized when $\mathrm{NiFe}_{2} \mathrm{O}_{4}$ and tannin were modified. This biological approach results in low costs and low environmental risks [31].

i. Synthesis of $\mathrm{NiFe}_{2} \mathrm{O}_{4}$ magnetic nanoparticles and modification of $\mathrm{NiFe}_{2} \mathrm{O}_{4}$ MNPs by tannin

Nickel Iron Oxide $\left(\mathrm{NiFe}_{2} \mathrm{O}_{4}\right)$ MNPs were synthesized by the solvothermal method [30]. $\mathrm{NiFe}_{2} \mathrm{O}_{4}$ has a narrow band gap and semiconductors material in a broad application. $\mathrm{NiFe}_{2} \mathrm{O}_{4}$ exhibits lower photocatalytic activity because of a fast recombination of photoelectron-hole pairs. The morphological and the particle size were determined using a field-emission scanning electron microscope (FE-SEM, SUAPR55, Germany Zeiss) with energy-disperse X-ray spectroscopy (EDS) [32].

ii. Glucose oxidase immobilization and protein assay

During the glucose immobilization, a similar approach was carried out as in Section (A) above and different chemical additive sodium phosphate buffer solutions were used during the glucose oxidase immobilization and protein assay production. Under certain conditions, the desired photo-biocatalyst $\mathrm{NiFe}_{2} \mathrm{O}_{4}$ / T / GOx was obtained, as stated by Bradford et al. [33].

Table II below indicates various samples and their efficacy, but it was observed that the photo-biocatalyst $\mathrm{NiFe}_{2} \mathrm{O}_{4} / \mathrm{T}$ / Gox-UV had a higher removal ratio after $90 \mathrm{~min}$.
Based on the two Fenton processes and UV light conditions, it was also shown that UV had a good affinity in the higher removal ratio after 90 min relative to Fenton.

TABLE II: KINETICS DATA OF IC REMOVAL IN THE PRESENCE OF A CATALYST [31].

\begin{tabular}{ccc}
\hline Samples & $\begin{array}{c}\text { Rate constants, } \mathrm{k} \\
\left(\mathrm{min}^{-1}\right)\end{array}$ & $\begin{array}{c}\text { decolourization } \\
\text { ratios after } 90 \mathrm{~min} \\
(\%)\end{array}$ \\
\hline $\mathrm{NiFe}_{2} \mathrm{O}_{4}-\mathrm{Fe}$ & 0.0034 & 25.3 \\
$\mathrm{NiFe}_{2} \mathrm{O}_{4}-\mathrm{UV}$ & 0.0037 & 29.7 \\
$\mathrm{NiFe}_{2} \mathrm{O}_{4} / \mathrm{T}-\mathrm{Fe}$ & 0.0040 & 32.9 \\
$\mathrm{NiFe}_{2} \mathrm{O}_{4} / \mathrm{TUV}$ & 0.0047 & 41.6 \\
$\mathrm{NiFe}_{2} \mathrm{O}_{4} / \mathrm{T} /$ & 0.0044 & 37.6 \\
$\mathrm{GOx}-\mathrm{Fe}$ & & \\
$\mathrm{NiFe}_{2} \mathrm{O}_{4} / \mathrm{T} /$ & 0.0545 & 98.6 \\
$\mathrm{GOx}-\mathrm{UV}$ & & \\
\hline
\end{tabular}

\section{ZnAlLDH-HRP biohybrid Photo-biocatalyst}

The essential organic compounds with poisonous, mutagenic and carcinogenic effects are phenols and their degradation derivatives [34]. Several methods have also been used for the depollution of organic compounds (phenols and their derivatives) in aqueous solution, such as filtration, flotation, dilution,

adsorption, physicochemical, biological and photochemical approaches [35].

TABLE III: CATALYTIC PERFORMANCES OF PHENOL DEGRADATION FOR PHOTO-BIOCATALYTIC AND ENZYMATIC PROCESSES [35].

\begin{tabular}{|c|c|c|c|c|}
\hline \multicolumn{2}{|c|}{ ZnAlLDH + hv } & HRP & $\begin{array}{c}\text { ZnAlLDH } \\
-\mathrm{HRP}\end{array}$ & $\begin{array}{c}\text { ZnAlLDH } \\
-\mathrm{HRP}+\mathrm{hv}\end{array}$ \\
\hline $\begin{array}{c}\% \text { Phenol } \\
\text { degradation }\end{array}$ & 20 & 41 & 25 & 35 \\
\hline 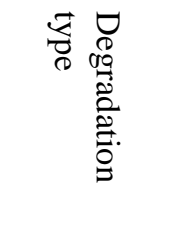 & 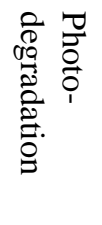 & 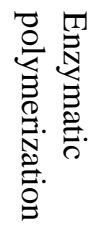 & 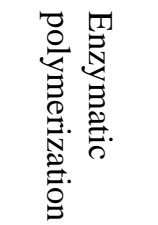 & 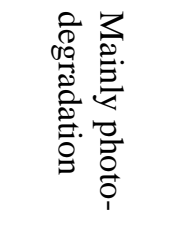 \\
\hline
\end{tabular}

Layered hydroxide layers (LDHs), Horseradish peroxidase (HRP) and Zinc Aluminum Alloy ( $\mathrm{ZnAl}$ ) were used for the synthesis of the photo-biocatalyst. Under solar irradiation, the ZnAlLDH - HRP biohybrid demonstrates an improvement in efficiency relative to $\mathrm{ZnAlLDH}$.

Even if the HRP is an effective biocatalyst in limited amounts, it is toxic, vulnerable to denaturation and inactivation [36]. $\mathrm{ZnCrLDH}$ and its derivative formulations have been identified as good materials for photo-degradation of rhodamine B by Liu et al. [37], methylene blue Chen et al. [38], orange II, 4-chlorophenol Paušová et al. [39], 2-nitrophenol, rhodamine 6G Mohapatra et al [36] and naphthalene Xia et al. [41], photocatalytic reduction of $\mathrm{CO}_{2}$ Katsumata Wang et al. [38], water splitting Wang et al. [43] and $\mathrm{H}_{2}$ production Luo et al. [44] under visible light. 


\section{i. Synthesis of photo-biocatalysts}

The preparation of $\mathrm{ZnCr} \mathrm{LDH}$ powder was reported by Gunjakar et al [45] with an addition of $\mathrm{NaOH}$ at a certain condition in order to obtain $\mathrm{ZnCr} \mathrm{LDH}$ nanosheets. Since the $\mathrm{O}_{2}$ generation caused by visible light occurs primarily on the surface of $\mathrm{Zn}-\mathrm{Cr}-\mathrm{LDH}$. Exciting progress has been made in the development of new synthesis methods; According to Luo, Song [44] composites with a different mass ratio of $\mathrm{ZnCr} \mathrm{LDH}$ nanosheets modified $\mathrm{g}-\mathrm{C}_{3} \mathrm{~N}_{4}$ were obtained [45].

It is revealed on Table III below that ZnAlLDH- HRP + hv photo-biocatalyst had mainly influence on the photo-degradation of organic pollutants (phenols). The inclusiveness of $+\mathrm{hv}$ has greater effectiveness in the depollution and the removal of organics pollutants. Tough the HRP also played a vital role as an anti-recalcitrant pollutant, the UV or $\mathrm{UV}$-vis enhanced the process.

\section{D. $\mathrm{GOx} / \mathrm{TiO}_{2} / \mathrm{PU}$ Photo-biocatalyst}

Efforts have been made in recent years to develop heterogeneous catalytic processes by integrating photo-catalysis with biological systems [46, 47]. Later, a photo-biocatalyst containing glucose oxidase immobilized with $\mathrm{TiO}_{2}$ / polyurethane was successfully used under UV for the removal of orange acid 7 [15]. Biological processes are inexpensive and environmentally sustainable alternatives for the treatment or the disinfection of wastewater [48].

Hybrid techniques, combined with photochemical and biochemical processes, have recently been widely attractive and shown to be more effective for reducing contaminants as well as reported by Shoabargh et al. [15].

Glucose oxidase (GOx) was immobilized with $\mathrm{TiO}_{2}$ / polyurethane (PU). This process has been tested for the elimination of Acid Orange 7 (AO7). Fast removal efficiency (> 99\%) was achieved after 22 min using a $\mathrm{GOx} / \mathrm{TiO}_{2} / \mathrm{PU}$ photo-biocatalyst [15].

\section{i. The Immobilization of $\mathrm{TiO}_{2}$ nanoparticles on PU}

According to Shoabargh and Karimi [11] the immobilization of $\mathrm{TiO}_{2}$ nanoparticles on PU was conducted using the similar approach as section $\mathrm{B}$ and $\mathrm{C}$.

A similar approach was adopted by Bulmuş et al. [28] as Section A(i). However, parameters such as temperature, $\mathrm{pH}$ and chemical additives used for the immobilization of $\mathrm{TiO}_{2} \mathrm{NPs}$ on PU using the Sonoplus Ultrasonic Homogenizer HD 2200 (Germany) were different.

\section{ii. Preparing $\mathrm{GOx} / \mathrm{TiO}_{2} / \mathrm{PU}$ photo-biocatalyst}

The batch tests were conducted by Gumy et al. [27]. To obtain a successfully synthesized $\mathrm{GOx} / \mathrm{TiO}_{2} / \mathrm{PU}$ photo-biocatalyst, as stated by Shoabargh et al. [15] during the immobilization of GOx to $\mathrm{TiO}_{2}$ and PU.

Table IV below shows the decolourization process and the first-order rate constants which indicate a higher performance of $\mathrm{GOx} / \mathrm{TiO}_{2} / \mathrm{PU} / \mathrm{UV}$.
TABLE IV: COMPARISON OF THE FIRST-ORDER RATE CONSTANT (K) AND COEFFICIENT OF DETERMINATION $\left(\mathrm{R}^{2}\right)$ OF VARIOUS DECOLOURIZATION METHODS; [AO7] $=20 \mathrm{MG} / \mathrm{L}, 258 \mathrm{C} ; \mathrm{TIO} / \mathrm{PU}=0.42 \mathrm{G} / \mathrm{G}$, AND RECYCLING $\mathrm{RATE}=5 \mathrm{ML} / \mathrm{MIN}[15]$.

\begin{tabular}{|c|c|c|}
\hline Decolourization process & $\mathrm{k}\left(\min ^{1}\right)$ & $\mathrm{R}^{2}$ \\
\hline $\mathrm{GOx} / \mathrm{PU}$ & 0.009 & 0.997 \\
\hline $\mathrm{TiO}_{2} / \mathrm{PU} / \mathrm{UV}$ & 0.0203 & 0.999 \\
\hline $\mathrm{GOx} / \mathrm{TiO}_{2} / \mathrm{PU}$ & 0.0360 & 0.998 \\
\hline $\begin{array}{c}\mathrm{GOx} / \mathrm{TiO}_{2} / \mathrm{UV} \text {-without } \\
\text { glucose }\end{array}$ & 0.0521 & 0.998 \\
\hline $\mathrm{GOx} / \mathrm{TiO}_{2} / \mathrm{PU} / \mathrm{UV}$ & 0.207 & 0.998 \\
\hline
\end{tabular}

E. Corn silk/TiO2 photo-biocatalyst

The consideration of UV-Vis during the degradation of a pollutant (dye) using photo-biocatalyst was reported by Nadaroglu et al. [49]. The wavelength of a range of 300 to 900 nm was observed [49].

\section{i. Synthesis of corn silk/ $/ \mathrm{TiO}_{2}$ photo-biocatalyst}

The pioneering work of corn $\operatorname{silk} / \mathrm{TiO}_{2}$ as a photo-biocatalyst, was reported by Nadaroglu et al. [49].

Photo-catalyst material of corn silk - $\mathrm{TiO}_{2}$ was used and successfully applied to the degradation of Reactive Black 5 (RB5) as a typical azo dye under UV radiation. Quick discolouration capability (> $99 \%$ ) was achieved after 30 s using corn silk / $\mathrm{TiO}_{2}$ photo-biocatalyst [49].

Various plant leaves or seeds can be used with a semiconductor to produce a pho-biocatalyst which may be useful during the removal of organic contaminants. The presence of UV contributes to the greater yield of the removal of organics pollutants.

The fact that the green synthesis biomolecules have a functional group that can be related to the ion metals. During this mixture of metal ions and biomolecules, the metal salt is reduced. This greener synthesis thus gives good sensitivity to its applications in diverse ways and further strengthens its assurance that fewer contaminants can be emitted during its biological applications. 


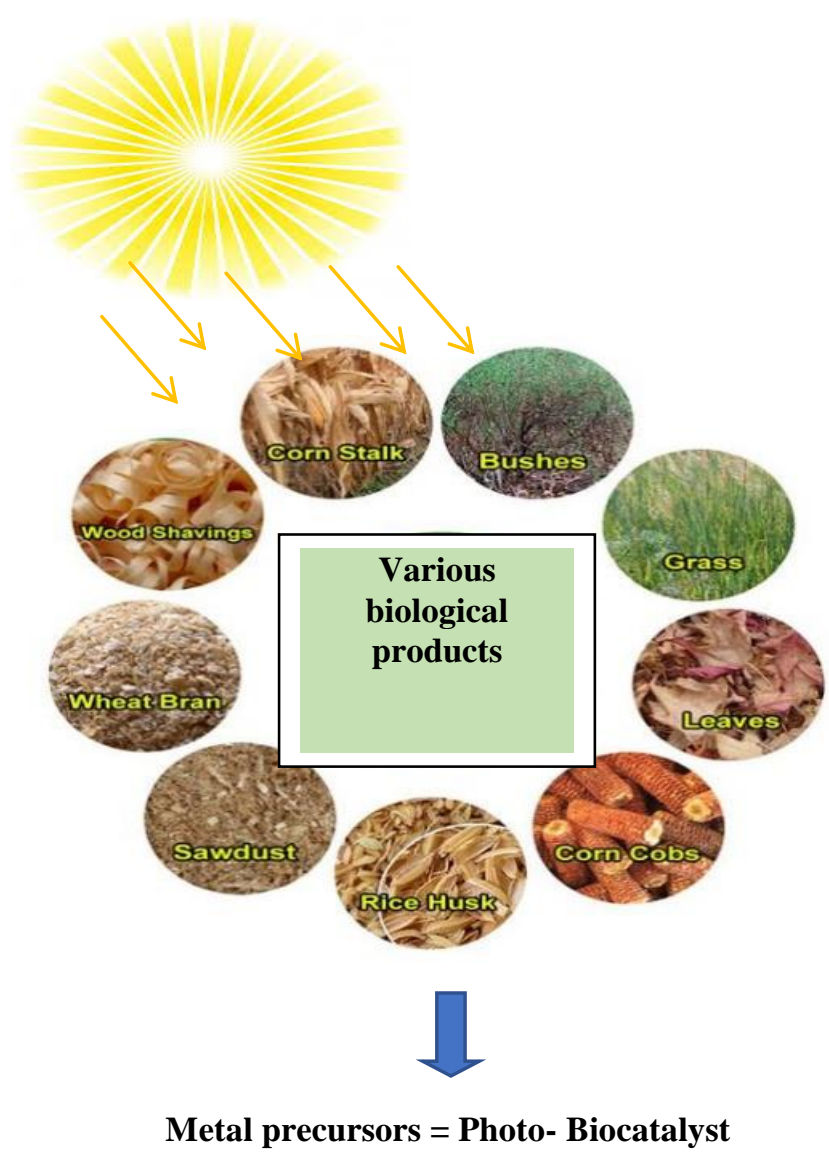

Fig. 1: The photo-degradation from the combination of semiconductors and the biologicals products.

The improvement of the efficiency of the removal of pollutants can be achieved from a combination of metals oxide with an agro-waste.

\section{Reusability Of The Photo-Biocatalyst}

Reusability is one of the most significant considerations in catalytic science. It shows the skill and its usefulness in responding to the repetition of how many circles can be used all over again. This also included interactions between the materials used in the construction of the photo-biocatalyst using ion exchanges or chemical processes that could be responsible for holding the bonds among the compounds that are being used during the synthesis. The reusability of the photo-biocatalyst emphasizes its effectiveness during the enhancement on the removal of pollutants in various aqueous solutions, furthermore, it also covers the cost-effectiveness in the production. It is vital to construct a photo-biocatalyst that can have an affinity of being reusable as many times as possible.

\section{CONCLUSION}

The physico-chemical properties of photo-biocatalysts are determined by the enhancement of biogenic synthesis contributing to the success in the elimination of many organic contaminants. While the photo-biocatalyst can also be effective, several research studies have shown that its efficacy pertains to the agro-synthesis. During the synthesis of photo-biocatalyst using metal oxides as agents, the organic compounds can potentially be activated by the aqueous solution. The incorporation of biological products has a larger effect with or without the influence of UV or UV-Vis. However, it showed greater yield with additional solar radiation or visible light.

\section{ACKNOWLEDGEMENT}

The authors are thankful to the sponsors: the Water Research Commission (WRC, Project 2974) and the North-West University in South Africa.

\section{REFERENCES}

[1]Lee KM, Lai CW, Ngai KS, Juan JC. Recent developments of zinc oxide based photocatalyst in water treatment technology: a review. Water research. 2016;88:428-48. https://doi.org/10.1016/j.watres.2015.09.045

[2]Nthambeleni Mukwevho, Elvis Fosso-Kankeu, Frans Waanders, Neeraj Kumar, Suprakas Sinha Ray, Xavier Yangkou Mbianda. 2019. Evaluation of the photocatalytic activity of $\mathrm{Gd}_{2} \mathrm{O}_{2} \mathrm{CO}_{3} \cdot \mathrm{ZnO} \cdot \mathrm{CuO}$ nanocomposite used for the degradation of phenanthrene. Springer Nature Applied Sciences. https://doi.org/10.1007/s42452-018-0012-0. $1-10$.

[3]Nthambeleni Mukwevho, Elvis Fosso-Kankeu, Frans Waanders, John Bunt, Dewald de Bruyn, Neeraj Kumar and Suprakas Sinha Ray. 2018. Sol-gel preparation of $\mathrm{ZnO} / \mathrm{SnO} 2$ composite photocatalysts applied for the degradation of PAH's under visible light. Editors: Elvis Fosso-Kankeu, Frans Waansders, Michel Plaisent. 10th Int'l Conference on Advances in Science, Engineering, Technology \& Healthcare (ASETH-18) Nov. 19-20, 2018 Cape Town (South Africa). ISBN: 978-81-938365-2-1. Vol II. Pp 173-177.

[4]N Mukwevho, N Kumar, E Fosso-Kankeu, F Waanders, J Bunt, SS Ray. 2019. Visible light-excitable $\mathrm{ZnO} / 2 \mathrm{D}$ graphitic-C3N4 heterostructure for the photodegradation of naphthalene. Desalination and Water Treatment. 163: $286-296$ https://doi.org/10.5004/dwt.2019.24422

[5]Nthambeleni Mukwevho, Rashi Gusain, Elvis Fosso-Kankeu, Neeraj Kumar, Frans Waanders, Suprakas Sinha Ray. 2020. Removal of naphthalene from simulated wastewater through adsorption-photodegradation by $\mathrm{ZnO} / \mathrm{Ag} / \mathrm{GO}$ nanocomposite. Journal of Industrial and Engineering Chemistry. 81: 393-404. https://doi.org/10.1016/j.jiec.2019.09.030

[6] Grosu E-F, Cârjă G, Froidevaux R. Development of peroxidase/layered double hydroxide hybrid catalysis for phenol degradation. Research on Chemical Intermediates. 2018;44(12):7731-52. https://doi.org/10.1007/s11164-018-3583-x

[7] Natarajan S, Bajaj HC, Tayade RJ. Recent advances based on the synergetic effect of adsorption for removal of dyes from waste water using photocatalytic process. Journal of Environmental Sciences. 2018;65:201-22. https://doi.org/10.1016/j.jes.2017.03.011

[8]Zhou Y, Lu J, Zhou Y, Liu Y. Recent advances for dyes removal using novel adsorbents: a review. Environmental pollution. 2019;252:352-65. https://doi.org/10.1016/j.envpol.2019.05.072

[9]Silva TL, Ronix A, Pezoti O, Souza LS, Leandro PK, Bedin KC, et al. Mesoporous activated carbon from industrial laundry sewage sludge: Adsorption studies of reactive dye Remazol Brilliant Blue R. Chemical Engineering Journal. 2016;303:467-76. https://doi.org/10.1016/j.cej.2016.06.009

[10] Athanasekou CP, Likodimos V, Falaras P. Recent developments of $\mathrm{TiO}_{2}$ photocatalysis involving advanced oxidation and reduction reactions in water. Journal of environmental chemical engineering. 2018;6(6):7386-94. https://doi.org/10.1016/j.jece.2018.07.026

[11] Pal S, Mondal S, Maity J, Mukherjee R. Synthesis and characterization of $\mathrm{ZnO}$ nanoparticles using moringa oleifera leaf extract: Investigation of photocatalytic and antibacterial activity. International Journal of Nanoscience and Nanotechnology. 2018;14(2):111-9. 
[12] Gautam PK, Singh A, Misra K, Sahoo AK, Samanta SK. Synthesis and applications of biogenic nanomaterials in drinking and wastewater treatment. Journal of environmental management. 2019;231:734-48. https://doi.org/10.1016/j.jenvman.2018.10.104

[13] Karimi P, Javanshir S, Sayadi MH, Arabyarmohammadi H. Arsenic removal from mining effluents using plant-mediated, green-synthesized iron nanoparticles. Processes. 2019;7(10):759. https://doi.org/10.3390/pr7100759

[14] Sousa M, Gonçalves C, Vilar VJ, Boaventura RA, Alpendurada M. Suspended TiO2-assisted photocatalytic degradation of emerging contaminants in a municipal WWTP effluent using a solar pilot plant with CPCs. Chemical Engineering Journal. 2012;198:301-9. https://doi.org/10.1016/j.cej.2012.05.060

[15] Shoabargh S, Karimi A, Dehghan G, Khataee A. A hybrid photocatalytic and enzymatic process using glucose oxidase immobilized on TiO2/polyurethane for removal of a dye. Journal of Industrial and Engineering Chemistry. 2014;20(5):3150-6. https://doi.org/10.1016/j.jiec.2013.11.058

[16] Daghrir R, Drogui P, Robert D. Photoelectrocatalytic technologies for environmental applications. Journal of Photochemistry and Photobiology A: Chemistry. 2012;238:41-52.

https://doi.org/10.1016/j.jphotochem.2012.04.009

[17] Dai Y, Yin L, Niu J. Laccase-carrying electrospun fibrous membranes for adsorption and degradation of PAHs in shoal soils. Environmental science \& technology. 2011;45(24):10611-8. https://doi.org/10.1021/es203286e

[18] Laurenti E, Ghibaudi E, Ardissone S, Ferrari RP. Oxidation of 2, 4-dichlorophenol catalyzed by horseradish peroxidase: characterization of the reaction mechanism by UV-visible spectroscopy and mass spectrometry. Journal of Inorganic Biochemistry. 2003;95(2-3):171-6. https://doi.org/10.1016/S0162-0134(03)00101-6

[19] Laurenti E, Ghibaudi E, Todaro G, Ferrari RP. Enzymatic degradation of 2, 6-dichlorophenol by horseradish peroxidase: UV-visible and mass spectrophotometric characterization of the reaction products. Journal of inorganic biochemistry. 2002;92(1):75-81. https://doi.org/10.1016/S0162-0134(02)00488-9

[20] Wolff SP. [18] Ferrous ion oxidation in presence of ferric ion indicator xylenol orange for measurement of hydroperoxides. Methods in enzymology. 1994;233:182-9. https://doi.org/10.1016/S0076-6879(94)33021-2

[21] Martınez NSS, Fernández JF, Segura XF, Ferrer AS. Pre-oxidation of an extremely polluted industrial wastewater by the Fenton's reagent. Journal of hazardous materials. 2003;101(3):315-22. https://doi.org/10.1016/S0304-3894(03)00207-3

[22] Amadelli R, Molinari A, Vitali I, Samiolo L, Mura GM, Maldotti A. Photo-electro-chemical properties of $\mathrm{TiO}_{2}$ mediated by the enzyme glucose oxidase. Catalysis Today. 2005;101(3-4):397-405 https://doi.org/10.1016/j.cattod.2005.03.035

[23] Abdi P, Farzi A, Karimi A. Application of a hybrid enzymatic and photo-fenton process for investigation of azo dye decolorization on $\mathrm{TiO} 2 /$ metal-foam catalyst. Journal of the Taiwan Institute of Chemical Engineers. 2017;71:137-44.

https://doi.org/10.1016/j.jtice.2016.11.022

[24] Oller I, Malato S, Sánchez-Pérez J. Combination of advanced oxidation processes and biological treatments for wastewater decontamination-a review. Science of the total environment. 2011;409(20):4141-66. https://doi.org/10.1016/j.scitotenv.2010.08.061

[25] Mahdizadeh F, Karimi A, Ranjbarian L. Immobilization of glucose oxidase on synthesized superparamagnetic $\mathrm{Fe} 3 \mathrm{O} 4$ nanoparticles; application for water deoxygenation. Int J Sci Eng Res. 2012;3:516-20.

[26] Datta S, Christena LR, Rajaram YRS. Enzyme immobilization: an overview on techniques and support materials. 3 Biotech. 2013;3(1):1-9. https://doi.org/10.1007/s13205-012-0071-7

[27] Gumy D, Morais C, Bowen P, Pulgarin C, Giraldo S, Hajdu R, et al. Catalytic activity of commercial of $\mathrm{TiO}_{2}$ powders for the abatement of the bacteria (E. coli) under solar simulated light: influence of the isoelectric point. Applied Catalysis B: Environmental. 2006;63(1-2):76-84. https://doi.org/10.1016/j.apcatb.2005.09.013

[28] Bulmuş V, Ayhan H, Pişkin E. Modified PMMA monosize microbeads for glucose oxidase immobilization. The Chemical Engineering Journal and the Biochemical Engineering Journal. 1997;65(1):71-6.
https://doi.org/10.1016/S0923-0467(96)03156-9

[29] Shoaebargh S, Karimi A, Dehghan G. Performance study of open channel reactor on AO7 decolorization using glucose oxidase/TiO2/polyurethane under UV-vis LED. Journal of the Taiwan institute of chemical engineers. 2014;45(4):1677-84. https://doi.org/10.1016/j.jtice.2013.12.012

[30] Jiao Q, Wang Y, Hao L, Li H, Zhao Y. Synthesis of magnetic nickel ferrite microspheres and their microwave absorbing properties. Chemical Research in Chinese Universities. 2016;32(4):678-81. https://doi.org/10.1007/s40242-016-5457-3

[31] Atacan K, Güy N, Cakar S, Özacar M. Efficiency of glucose oxidase immobilized on tannin modified $\mathrm{NiFe} 2 \mathrm{O} 4$ nanoparticles on decolorization of dye in the Fenton and photo-biocatalytic processes. Journal of Photochemistry and Photobiology A: Chemistry. 2019;382:111935. https://doi.org/10.1016/j.jphotochem.2019.111935

[32] Atacan K, Çakıroğlu B, Özacar M. Efficient protein digestion using immobilized trypsin onto tannin modified $\mathrm{Fe}_{3} \mathrm{O}_{4}$ magnetic nanoparticles. Colloids and Surfaces B: Biointerfaces. 2017;156:9-18. https://doi.org/10.1016/j.colsurfb.2017.04.055

[33] Bradford MM. A rapid and sensitive method for the quantitation of microgram quantities of protein utilizing the principle of protein-dye binding. Analytical biochemistry. 1976;72(1-2):248-54.

https://doi.org/10.1016/0003-2697(76)90527-3

[34] KdQ, Nunes DG, Rubio J. Removal of phenol by enzymatic oxidation and flotation. Brazilian Journal of Chemical Engineering. 2000; 17(4-7):907-14 https://doi.org/10.1590/S0104-66322000000400055

[35] Guomin C, Guoping Y, Mei S, Yongjian W. Chemical industrial wastewater treated by combined biological and chemical oxidation process. Water Science and Technology. 2009;59(5):1019-24. https://doi.org/10.2166/wst.2009.051

[36] Kim SJ, Song BK, Yoo YJ, Kim YH. Peroxidase inactivation by covalent modification with phenoxyl radical during phenol oxidation. Journal of the Korean Society for Applied Biological Chemistry. 2014;57(6):743-7. https://doi.org/10.1007/s13765-014-4221-y

[37] Liu Q, Ma J, Wang K, Feng T, Peng M, Yao Z, et al. BiOCl and TiO2 deposited on exfoliated $\mathrm{ZnCr}-\mathrm{LDH}$ to enhance visible-light photocatalytic decolorization of Rhodamine B. Ceramics International. 2017;43(7):5751-8. https://doi.org/10.1016/j.ceramint.2017.01.119

[38] Chen D, Li Y, Zhang J, Zhou J-Z, Guo Y, Liu H. Magnetic $\mathrm{Fe} 3 \mathrm{O} 4 / \mathrm{ZnCr}$-layered double hydroxide composite with enhanced adsorption and photocatalytic activity. Chemical Engineering Journal. 2012;185:120-6.

https://doi.org/10.1016/j.cej.2012.01.059

[39] Paušová Š, Krýsa J, Jirkovský J, Forano C, Mailhot G, Prevot V. Insight into the photocatalytic activity of $\mathrm{ZnCr}-\mathrm{CO} 3 \mathrm{LDH}$ and derived mixed oxides. Applied Catalysis B: Environmental. 2015;170:25-33. https://doi.org/10.1016/j.apcatb.2015.01.029

[40] Mohapatra L, Parida K. Zn-Cr layered double hydroxide: visible light responsive photocatalyst for photocatalytic degradation of organic pollutants. Separation and purification technology. 2012;91:73-80. https://doi.org/10.1016/j.seppur.2011.10.028

[41] Xia S, Zhang L, Zhou X, Shao M, Pan G, Ni Z. Fabrication of highly dispersed $\mathrm{Ti} / \mathrm{ZnO}-\mathrm{Cr} 2 \mathrm{O} 3$ composite as highly efficient photocatalyst for naphthalene degradation. Applied Catalysis B: Environmental. 2015; 176:266-77. https://doi.org/10.1016/j.apcatb.2015.04.008

[42] Katsumata K-i, Sakai K, Ikeda K, Carja G, Matsushita N, Okada K. Preparation and photocatalytic reduction of $\mathrm{CO} 2$ on noble metal $(\mathrm{Pt}, \mathrm{Pd}$, $\mathrm{Au})$ loaded $\mathrm{Zn}-\mathrm{Cr}$ layered double hydroxides. Materials Letters. 2013; 107:138-40. https://doi.org/10.1016/j.matlet.2013.05.132

[43] Wang C, Ma B, Xu S, Li D, He S, Zhao Y, et al. Visible-light-driven overall water splitting with a largely-enhanced efficiency over a Cu2O@ ZnCr-layered double hydroxide photocatalyst. Nano Energy. 2017;32:463-9.

https://doi.org/10.1016/j.nanoen.2017.01.010 
[44] Luo B, Song R, Jing D. ZnCr LDH nanosheets modified graphitic carbon nitride for enhanced photocatalytic hydrogen production. International Journal of Hydrogen Energy. 2017;42(37):23427-36. https://doi.org/10.1016/j.ijhydene.2017.03.001

[45] Gunjakar JL, Kim TW, Kim IY, Lee JM, Hwang S-J. Highly efficient visible light-induced $\mathrm{O} 2$ generation by self-assembled nanohybrids of inorganic nanosheets and polyoxometalate nanoclusters. Scientific reports. 2013;3:2080. https://doi.org/10.1038/srep02080

[46] Hamdi H, Namane A, Hank D, Hellal A. Coupling of photocatalysis and biological treatment for phenol degradation: application of factorial design methodology. J Mater. 2017;8:3953-61.

[47] Xiong H, Zou D, Zhou D, Dong S, Wang J, Rittmann BE. Enhancing degradation and mineralization of tetracycline using intimately coupled photocatalysis and biodegradation (ICPB). Chemical Engineering Journal. 2017;316:7-14 https://doi.org/10.1016/j.cej.2017.01.083

[48] Munoz R, Guieysse B. Algal-bacterial processes for the treatment of hazardous contaminants: a review. Water research. 2006;40(15):2799-815 https://doi.org/10.1016/j.watres.2006.06.011

[49] Nadaroglu H, Lesani A, Soleimani SS, Babagil A. A newly green hotocatalyst support for azo dye remediation under UV light irradiation. Applied Water Science. 2018;8(4):107. https://doi.org/10.1007/s13201-018-0752-4 